\title{
Identification of phenolic compounds, antibacterial and antioxidant activities of raisin extracts
}

\author{
Yousef M. Abouzeed ${ }^{1, *}$, Faraj Zgheel ${ }^{2}$, Abdurrezagh Abdalla Elfahem², Mohammed Saad Almagarhe ${ }^{2}$, \\ Abdulgader Dhawi ${ }^{1}$, Abdulkareem Elbaz ${ }^{1}$, Murad A. Hiblu ${ }^{3}$, Abdulwahab Kammon ${ }^{4}$ and Mohamed O. Ahmed ${ }^{1}$ \\ ${ }^{1}$ Department of Microbiology and Parasitology, Faculty of Veterinary Medicine, University of Tripoli, Tripoli, \\ Libya \\ ${ }^{2}$ Department of Microbiology, Biotechnology Research Centre, Tripoli, Libya \\ ${ }^{3}$ Department of Internal Medicine, Faculty of Veterinary Medicine, University of Tripoli, Tripoli, Libya \\ ${ }^{4}$ Department of Poultry and Fish Diseases, Faculty of Veterinary Medicine, University of Tripoli, Tripoli, Libya
}

\begin{abstract}
In this study, antibacterial, antioxidant and phenolic compounds of raisin extracts was evaluated. Different solvent extraction methods were utilized to extract phenolic compounds from raisin. The phenolic compounds of raisin extracts was determined using HPLC and three compounds were found, catechin, quercetin and rutin. The antibacterial activity of the acetonic extract was tested against four bacterial pathogens viz. Staphylococcus aureus, Pseudomonas aeroginosa, Salmonella typhimurium and Escherichia coli using both disk diffusion and minimum inhibitory concentration (MIC) methods. The acetonic extract exhibited the highest activity against Staphylococcus aureus with zone of inhibition of $14 \mathrm{~mm}$ and the MIC of $25 \mathrm{mg} / \mathrm{ml}$. However, there was a little activity against $E$. coli and $S$. typhimurium. The methanolic extract showed good antioxidant activity as indicated by 2,2-diphenyl-1-picrylhydrazyl free radical assay (DPPH). In conclusion, raisin contains potent phenolic compounds and their application might function as promising natural preservative and antimicrobial agents in food industry and also good antioxidant food that helps to minimize the risk of degenerative diseases.
\end{abstract}

Keywords: Antibacterial, Antioxidant, Phenolic compounds, Raisin extract.

\section{Introduction}

Bioactive compounds extracted from natural sources can benefit human health (Samavardhana et al., 2015). Plants are natural source of antimicrobial agents with great therapeutic values. According to world health organization (WHO) about $80 \%$ of the population in developed countries use plants and their extracts as medicine. Many drugs used in modern medicine are originated from natural sources (Okoko and Oruambo, 2008). Similarly, many researchers have demonstrated the usefulness of different plant compounds as effective antimicrobial agent (Szeto et al., 2002; Jimoh et al., 2008).

Raisins (dried grapes; Vitis vinifera), ), are very popular plant in Mediterranean area and are widely used as a traditional and natural biomedicine in several countries where it is well adapted to the climate (Di Lorenzo et al., 2016; Cordero-Bueso et al., 2017). Raisins are considered to be a good source of monomeric catechins, epicatecthins, gallic acids and polymeric procyandins which have an overall beneficial effect on human health (Monagas et al., 2005). The sweetness of raisins was attributed to the presence of glucose and fructose (Winkler, 1962). Previous studies demonstrated that the various phytochemical compounds in raisin such as polyphenol have both antioxidant and antimicrobial activities (Jayaprakasha et al., 2003; Baydar et al., 2004). Raisins contain the highest concentration of total phenolic compounds and the highest antioxidant activity among dried fruits (Karakaya et al., 2001). The antioxidant property of raisins was also attributed to phenolic compounds (Yeung et al., 2006). These findings supporting the idea of using raisin extracts as antioxidants in food systems. The phenolic contents and antimicrobial activities of raisins have previously been studied and found to be highly correlated (Bower et al., 2003). The average distributions of polyphenolic compounds in raisins were estimated to be about 5 per cent in juice, 1 per cent in pulp and the remaining 62 per cent in the seeds (Singletary et al., 2003).

It is also well known fact that spoilage of foodstuff due to microbial contamination is a serious problem. Generally, chemical additives are employed to prevent spoilage of food but many of them are carcinogenic. Recent studies, reported that some plant compounds can safely be used for preventing microbial spoilage of food, thus ensuring quality, safety and shelf life of foods. Therefore, the application of plant extracts to prevent food spoilage has been increased throughout the world (Baydar et al., 2004). 
The aim of this study was to investigate the presence of phenolic compounds in raisins sold in Libyan market and also to evaluate their antibacterial and antioxidant activity of those compounds.

\section{Sample preparation}

Materials and Methods

The raisin fruit purchased from local market were washed, cleaned, dried at $60^{\circ} \mathrm{C}$ for 30 minutes and then grinded. The extraction was carried out using conventional solvent extraction procedure. Ten grams of homogenized raisin were extracted with $100 \mathrm{ml}$ of methanol $95 \%$ at $60{ }^{\circ} \mathrm{C}$ for 60 minutes. Following extraction, the samples were filtered through Whatman No.1 filter paper and the residue was re-extracted with the same solvent. The filtrates were combined and dried in a rotary evaporator at $50^{\circ} \mathrm{C}$. The extracts so obtained were used for spectrophotometer analysis and high performance liquid chromatography (HPLC) measurements. For testing the antibacterial activity of the raisin, the extraction was carried out using acetone $95 \%$ for $72 \mathrm{~h}$.

\section{Bacterial strains}

The bacterial strains used in this study are Staphylococcus aureus, Pseudomonas aeroginosa, Escherichia coli and Salmonella typhimurium. The strains were obtained from the stock culture collection of the Microbiology Department of the Biotechnology Research Center. All tested bacteria were pre-cultured in nutrient broth overnight at $37^{\circ} \mathrm{C}$.

\section{Screening of antibacterial activity}

The antimicrobial activity of the raisin acetonic extract was evaluated against the selected microorganisms using disc diffusion method (Bauer et al., 1966). Briefly, $20 \mathrm{ml}$ of Mueller Hinton agar was poured in sterile petri plates and allowed to solidify. Thereafter, $0.2 \mathrm{ml}$ of overnight broth cultures was streaked on Mueller-Hinton agar (MHA) to make a complete lawn. Sterile $6 \mathrm{~mm}$ filter paper discs (Whatman. No. 3) were soaked in extract for $30 \mathrm{~min}$. After completely drying the discs at $55^{\circ} \mathrm{C}$, they were plated on MHA. A cefotaxime sodium disk (10 $\mu \mathrm{g} / \mathrm{disk})$ was used as a positive control. The experiment was conducted in triplicate to minimize errors. All plates were incubated at $37{ }^{\circ} \mathrm{C}$ for $24 \mathrm{~h}$, after that, inhibition zone of was measured and the results recorded.

\section{Determination of minimum inhibitory concentration}

The dilution method was used to determine minimum inhibitory concentration (MIC) of acetonic extract in 96 well microtitre plates. Stock solution of raisin extract $(200 \mathrm{~m} / \mathrm{ml})$ was prepared by dissolving in DMSO:water $(4: 2 \mathrm{v} / \mathrm{v})$ solvent. One hundred microliters of sterile nutrient broth were poured in all the wells and $100 \mu \mathrm{l}$ of stock solution was transferred to well A to obtain a concentration of $100 \mathrm{mg} / \mathrm{ml}$. Thereafter, serial dilution was performed till the lowest concentration i.e. $6.25 \mathrm{mg} /$ $\mathrm{ml}$ was obtained. The solvent used to dissolve the extract was also tested against the microorganisms to ensure the antibacterial activity of the solvent. Then $100 \mu \mathrm{l}$ of each microorganism having concentration of $1 \times 10^{8} \mathrm{cfu} / \mathrm{ml}$ were poured in all the wells and incubated at $37^{\circ} \mathrm{C}$ for $24 \mathrm{~h}$. One plate for each microorganism species was used to avoid cross contamination between microorganisms. The presence of growth in all wells was checked by reculturing them on MHA and incubating again at $37{ }^{\circ} \mathrm{C}$ for $24 \mathrm{~h}$. The absence of growth at a particular concentration was then taken as the MIC for particular organism.

Determination of antioxidant activity 2,2-diphenyl-1-picrylhydrazyl free radical (DPPH) assay

The DPPH reagent (Sigma chemicals) was made to a concentration of $0.2 \% \mathrm{~m} / \mathrm{v}$ in methanol. Chromatogram eluted in two eluent systems, CEF (chloroform:ethyl acetate:formic acid, 20:16:4) and EMW (ethyl acetate:methanol:water, 20:10.8:8). Eluted plates were visualized under ultraviolet light at 254 and $360 \mathrm{~nm}$ and thereafter sprayed with DPPHradical, as described by Braca et al. (2001), and monitored for visual colour for 30 minutes.

\section{DPPH radical scavenging assay}

The free radical scavenging capacity of the methanolic extracts of raisin was determined using DPPH. DPPH solution $(0.004 \% \mathrm{w} / \mathrm{v})$ was prepared in $95 \%$ methanol. Methanolic extract of raisin was mixed with $95 \%$ methanol to prepare the stock solution $(10 \mathrm{mg} / 100 \mathrm{ml})$. From stock solution, $2 \mathrm{ml}, 4 \mathrm{ml}, 6 \mathrm{ml}, 8 \mathrm{ml}$ and $10 \mathrm{ml}$ were taken in five test tubes. Serial dilutions were made by adding same solvent in each tube to make a final volume of $10 \mathrm{ml}$ and finally, the concentration obtained were $20 \mu \mathrm{g} / \mathrm{ml}, 40 \mu \mathrm{g} / \mathrm{ml}, 60 \mu \mathrm{g} / \mathrm{ml}, 80 \mu \mathrm{g} / \mathrm{ml}$ and 100 $\mu \mathrm{g} / \mathrm{ml}$, respectively. Freshly prepared DPPH solution $(0.004 \% \mathrm{w} / \mathrm{v})$ was then added in each of these test tubes containing raisin extracts. After $10 \mathrm{~min}$, the absorbance was taken at $517 \mathrm{~nm}$ using a spectrophotometer. Ascorbic acid was used as a reference standard. Control sample was prepared containing the same volume without any extract and $95 \%$ methanol was used as blank.

Per cent scavenging of DPPH free radical was measured using the following equation.

Per cent DPPH radical- scavenging $=[$ (Absorbance of control - Absorbance of test sample / (Absorbance of control)] $* 100$

\section{Preparation of standard solution}

Standard stock solutions of three flavonoids i.e. catechin, quercetin and rutin were prepared in ethanol at concentration of $0.5 \mathrm{mg} / \mathrm{ml}$. All sample solutions were filtered through $0.54 \mu \mathrm{m}$ membrane and injected directly.

\section{HPLC Analysis}

HPLC was used to identify compounds in raisin extract. The analysis was performed using a 
SHMADZU SCL-10 AVP C18 column (100*4.6mm, $5 \mu \mathrm{m}$ particle size) equipped with an auto sampler and UV detector. The mobile phase was methanolacetonitrile-water (40:15:45 v/v/v) containing 1.0\% acetic acid. The column was eluted at $1.0 \mathrm{ml} \mathrm{min}$ the chromatogram. The chromatographic peak of the analysed data was confirmed by comparing their retention time and UV spectra with those of reference standard.

\section{Antibacterial activity}

\section{Results}

The activity of raisin acetonic extract against $S$. aureus, $P$. aeruginosa, E. coli, and S. typhimurium is illustrated in Table 1.

Our results indicated that the acetonic extract exhibited significant activity against the $S$. aureus. Whereas, the effect against other tested bacterial strains was nonsignificant as compared to the inhibitory zone of cefotaxime sodium standard.

The MIC value of acetonic extracts was $25 \mathrm{mg} / \mathrm{ml}$ against $S$. aureus and $100 \mathrm{mg} / \mathrm{ml}$ for the other tested bacteria (Table 2).

Table 1. Antibacterial activity of raisin acetonic extract by disk diffusion method

\begin{tabular}{lcc}
\hline Bacterial strain & $\begin{array}{c}\text { Cefotaxime } \\
\text { sodium }(\mathrm{mm})\end{array}$ & $\begin{array}{c}\text { Acetone } \\
\text { extract }(\mathrm{mm})\end{array}$ \\
\hline S. aureus & 20 & 14 \\
P. aeruginosa & 12 & 10 \\
S. typhimurium & 27 & 7 \\
E. coli & 25 & 7 \\
\hline
\end{tabular}

Table 2. Minimum Inhibitory Concentration (MIC) of acetonic extract of raisin $(\mathrm{mg} / \mathrm{ml})$.

\begin{tabular}{lccccccc}
\hline & \multicolumn{6}{c}{$\begin{array}{c}\text { Serial dilution of acetone raisin } \\
\text { extract }(\mathrm{mg} / \mathrm{ml})\end{array}$} \\
\cline { 2 - 7 } & 200 & 100 & 50 & 25 & 12.5 & 6.50 \\
\hline S. aureus & - & - & - & - & + & + \\
$P$. aeruginosa & - & - & + & + & + & + \\
Salmonella Spp. & - & - & + & + & + & + \\
E. coli & - & - & + & + & + & + \\
\hline
\end{tabular}

\section{Phytochemical screening of raisin extract Antioxidant activity of raisin DPPH Assay}

The raisin methanolic extracts showed profound antioxidant activity as compared to ascorbic acid which was indicated by their ability for scavenging DPPH free radical standard (Fig. 1).

The presence of yellow zones against a purple background on chromatograms depicted the scavenging activity of free radicals by compounds in the extracts (Fig. 2).

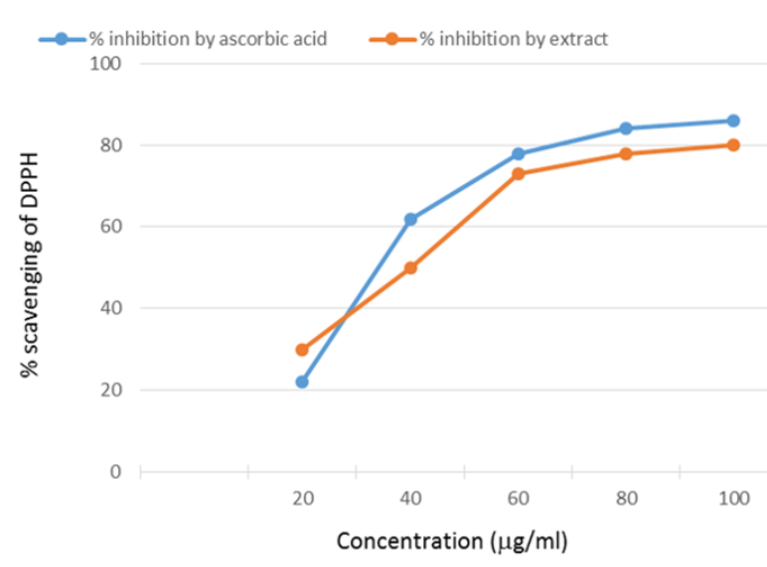

Fig. 1. DPPH radical scavenging activity of methanolic extract of raisin.

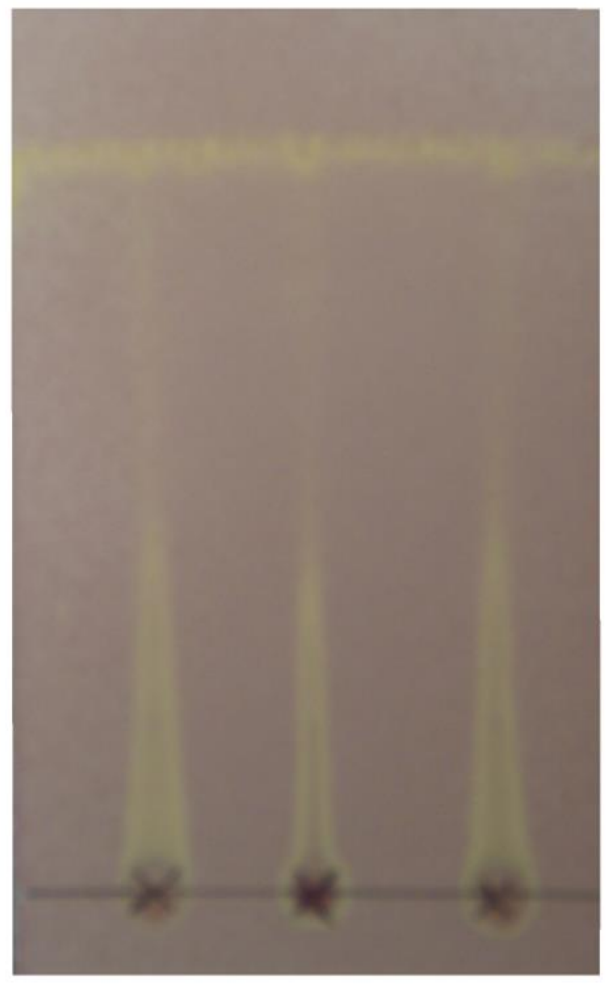

Fig. 2. Chromatogram developed in EMW and sprayed with $\mathrm{DPPH}$, with clear yellow zone indicating the antioxidant activity.

\section{HPLC-UV analysis}

Methanol-acetonitrile-water (40:15:45 v/v/v) results in separation of the polyphenolic compounds, catechin, rutin and quercetin. The presence of acid in a mobile phase system can improve peak trailing of compound and change $\mathrm{pH}$ value of the mobile phase, thus having a significant effect on the resolution of compounds. As a result, a mixture system of methanol-acetonitrilewater $(40: 15: 45 \mathrm{v} / \mathrm{v} / \mathrm{v})$ containing $1.0 \%$ acetic acid was confirmed as the optimum mobile phase. 


\section{Discussion}

The phytochemical screening of raisins revealed the presence of catechin, quercetin and rutin. These polyphenolic compounds were correlated to antioxidant and antimicrobial activity of raisins (Iacopini et al., 2008). Our results indicated that the acetonic extract exhibited significant activity against the $S$. aureus. Whereas, there was non-significant effect against other tested bacteria as compared to the inhibitory zone of cefotaxime sodium standard.

The MIC value of acetonic extracts was $25 \mathrm{mg} / \mathrm{ml}$ against $S$. aureus, while for the other tested bacterial strains, was $100 \mathrm{mg} / \mathrm{ml}$. Several researchers have focused on the bioactivity of polyphenolic compounds of grape as they possess a potential antioxidants and antimicrobials activities (de Bruyne et al., 1999; Jung et al., 2005; Chavez et al., 2006; Bruno and Sparapano, 2007). Our results are not in agreement with Rodriguez-Vaquero et al. (2007) who reported that grape wine inhibited the growth of E. coli. This could be assigned to the difference in the concentration of polyphenolic compounds of grape and raisin. The inhibition of growth increased as the polyphenol concentration increased, thus clarified wines were ineffective against all tested bacteria. Many bacterial species exhibited different sensitivities to phenolic compounds (Rodriguez-Vaquero et al., 2007). It has been reported that $S$. aureus was highly sensitive to wine extracts, followed by $E$. coli and the least effect was observed in Candida albicans (Papadopoulou et al., 2005).

Recently, few researchers reported that seed extracts has more antimicrobial potential than other parts of grapes (Shrestha et al., 2012). The MIC of seed extracts for Listeria was $0.26 \mathrm{mg}$ (Anastasiadi et al., 2009). The grape extracts from whole grape fruit inhibited bacterial growth at concentrations of 680 $\mathrm{mg} / \mathrm{L}$ and $1360 \mathrm{mg} / \mathrm{L}$ for gram positive and gram negative bacteria, respectively (Serra et al., 2008). However, Jayaprakasha et al. (2003) noted that grape seed extracts inhibited bacterial growth at $340-390$ $\mathrm{mg} / \mathrm{L}$ and $475-575 \mathrm{mg} / \mathrm{L}$ for gram positive and gram negative bacteria, respectively. The extract of grape leaves exhibited less antimicrobial activity than seed extracts. The extract from grape's flesh did not have antimicrobial effect (Yigit et al., 2009). The grape skin possessed the highest anti-Helicobacter pylori activity followed by synergy of skin and seed (Brown et al., 2009). The antimicrobial agents present in grape is distributed mainly in flesh, followed by whole fruit, followed by grape extracts, fermented pomace, skin, leave and seed (Shrestha et al., 2012).

Jayaprakash et al. (2003) reported that two different solvents system i.e. acetone: water: acetic acid (90: 9.5: 0.5) and methanol: water: acetic acid (90: 9.5: 0.5) were used for extraction and their results revealed that both extracts had activity against gram positive bacteria but not against gram negative bacteria. This could be attributed to the difference in the cell wall structure between gram positive and gram negative bacteria (Serra et al., 2008).

Antioxidant activity of raisin is tested using DPPH assay. Our result of DPPH assay shows that free radical scavenging ability of raisin extracts was almost similar to ascorbic acid under the test conditions. The antioxidant activity of raisin extracts is increased with an increase of its concentration (direct proportion). DPPH has been widely used in the determination of antioxidant activity of single compounds as well as the different plant extracts (Kulis 'ic' et al., 2004).

HPLC results in separation of the polyphenolic compounds, catechin, rutin and quercetin. Rutin is one of the phenolic compounds that contributes to the antibacterial properties of the plant (van der Watt and Pretorius, 2001). Quercetin has been reported to inhibit the oxidation of other molecules and hence is classified as an antioxidant (Russo et al., 2014). Catechin has been shown to be powerful inhibitor of in vitro human LDL oxidation (Teissedre et al., 1996). However, as flavonoids, catechins can act as antioxidants when in high concentration in vitro, but compared with other flavonoids, their antioxidant potential is low (Pietta, 2000). Another study concluded that catechins, whether from tea or other sources, might reduce the risk of ischaemic heart disease mortality (Arts et al., 2001)

\section{Acknowledgments}

The authors are grateful to the Biotechnology Research Centre and Faculty of Veterinary Medicine, University of Tripoli, Tripoli-Libya for providing necessary facilities and to The Libyan Authority for Research, Science and Technology for providing funds to conduct the research.

\section{Conflict of interest}

The authors declare that there is no conflict of interest.

\section{References}

Anastasiadi, M., Chorianopoulos, N.G., George-John, E.N. and Haroutounian, S.A. 2009. Antilisterial activities of polyphenol-rich extracts of grapes and vinification byproducts. J. Agric. Food Chem. 57, 457-463.

Arts, I.C.W., Hollman, P.C.H., Feskens, E.J.M., Bueno de Mesquita, H.B. and Kromhout, D. 2001. Catechin intake might explain the inverse relation between tea consumption and ischemic heart disease: The Zutphen elderly study. Am. J. Clin. Nutr. 74, 227-232.

Bauer, A.W., Kirby, W.M., Sherris, J.C. and Turck, M. 1966. Antibiotic susceptibility testing by a standardized single disk method. Am. J. Clin. Pathol. 45(4), 493-496. 
Baydar, H., Sagdiç, O., Özkan, G. and Karadogan, T. 2004. Antibacterial activity and composition of essential oils from Origanum, Thymbra and Satureja species with commercial importance in Turkey. Food Control 15, 169-172.

Bower, C.K., Schilke, K.F. and Daeschel, M.A. 2003. Antimicrobial Properties of Raisins in Beef Jerky Preservation. J. Food Sci. 68(4), 1484-1489.

Braca, A., Tommasi, N.D., Bari, L.D., Pizza, C., Politi, M. and Morelli I. 2001. Natural anti-oxidants from plant material in phenolic compounds in food and their effects on health. J. Nat. Prod. 64, 892-895.

Brown, J.C., Huang, G., Haley-Zitlin, V. and Jiang, X. 2009. Antibacterial effects of grape extracts on Helicobacter pylori. Appl. Environ. Microbiol. 75, 848-852.

Bruno, G. and Sparapano, L. 2007. Effects of three esca-associated fungi on Vitis vinifera L: V. Changes in the chemical and biological profile of xylem sap from diseased cv. Sangiovese vines. Physiol. Mol. Plant Pathol. 71, 210-229.

Chavez, J.H., Leal, P.C., Yunes, R.A., Nunes, R.J., Barardi, C.R., Pinto, A.R., Simoes, C.M. and Zanetti, C.R. 2006. Evaluation of antiviral activity of phenolic compounds and derivatives against rabies virus. Vet. Microbiol. 116, 53-59.

Cordero-Bueso, G., Mangieri, N., Maghradze, D., Foschino, R., Valdetara, F., Cantoral, J.M. and Vigentini, I. 2017. Wild Grape-Associated Yeasts as Promising Biocontrol Agents against Vitis vinifera Fungal Pathogens. Front. Microbiol. 8, 2025. Doi:10.3389/fmicb.2017.02025.

de Bruyne, T., Pieters, L., Witvrouw, M., de Clercq, E., Berghe, D.V. and Vlietinck, A.J. 1999. Biological evaluation of proanthocyanidin dimers and related polyphenols. J. Nat. Prod. 62, 954-958.

Di Lorenzo, M., Fernandez, T.V., Badalamenti, F., Guidetti, P., Starr, R.M., Giacalone, V.M., Di Franco, A. and D'Anna, G. 2016. Diel activity and variability in habitat use of white sea bream in a temperate marine protected area. Mar. Environ. Res. 116, 1-9.

Iacopini, P., Baldi, M., Storchi, P. and Sebastiani, L. 2008. Catechin, epicatechin, quercetin, rutin and resveratrol in red grape: Content, in vitro antioxidant activity and interactions. J. Food Compost. Anal. 21(8), 589-598.

Jayaprakasha, G.K., Tamil, S. and Sakartah, K.K. 2003. Antibacterial and antioxidant activities of grape (Vitis vinifera) seed extracts. Food Res. Int. 36, 117-122.

Jimoh, F.O., Adebayo, A.A., Aliero, A.A. and Afolayan, A.J. 2008. Polyphenol contents and biological activities of Rumex ecklonianus. Pharm. Biol. 45(5), 333-340.
Jung, H.J., Hwang, I.A., Sung, W.S., Kang, H., Kang, B.S., Seu, Y.B. and Lee, D.G. 2005. Fungicidal effect of resveratrol on human infectious fungi. Arch. Pharm. Res. 2, 557-560.

Karakaya, S., El, S.N. and Tas, A.A. 2001. Antioxidant activity of some foods containing phenolic compounds. Int. J. Food Sci. Nutr. 52, 501-508.

Kuliš 'ic', T., Radonic', A., Katalinic', V. and Milos`, M. 2004. Use of different methods for testing antioxidative activity of oregano essential oil. Food Chem. 85, 633-640.

Monagas, M., Hernandez-Ledesma, B., Garrido, P., Martin-alvarez, P.J., Gomez-Cordoves, C. and Bartolome, B. 2005. Quality assessment of commercial dietary antioxidant products from Vitis vinifera L. grape seeds. Nutr. Cancer 53, 244-254.

Okoko, T. and Oruambo, I.F. 2008. The effects of Hibiscus sabdariffa calyx on cisplatin-induced tissues damaged in rats. Biokemistri 20(2), 47-52.

Papadopoulou, C., Soulti, K. and Roussis, I.G. 2005. Potential antimicrobial activity of red and white wine phenolic extracts against strains of Staphylococcus aureus, Escherichia coli and Candida albicans. Food Technol. Biotechnol. 43, 41-46.

Pietta, P.G. 2000. Flavonoids as antioxidants. J. Nat. Prod. 63(7), 1035-1042.

Rodriguez-Vaquero, M.J., Alberto, M.R. and Mancade-Nadra, M.C. 2007. Influence of phenolic compounds from wines on the growth of Listeria monocytogenes. Food Control 18, 587-593.

Russo, G.L., Russo, M., Spagnuolo, C., Tedesco, I., Bilotto, S., Iannitti, R. and Palumbo, R. 2014. Quercetin: a pleiotropic kinase inhibitor against cancer. Cancer Treat. Res. 159, 185-205.

Samavardhana, K., Supawititpattana, P., Jittrepotch, N., Rojsuntomkitti, K. and Kongbangkerd, T. 2015. Effects of extracting conditions on phenolic compounds and antioxidant activity from different grape processing byproducts. Int. Food Res. J. 23(3), 1169-1179.

Serra, A.T., Matias, A.A., Nunes, A.V.M., Leitao, M.C., Brito, D., Bronze, R., Silva, S., Pires, A., Crespo, M.T., Romao, M.V.S. and Duarte, C.M. 2008. In vitro evaluation of olive- and grape-based natural extracts as potential preservatives for food. Inno. Food Sci. Emerg. Technol. 9, 311-319.

Shrestha, B., Theerathavaj, M.L., Thaweboon, S. and Thaweboon, B. 2012. In vitro antimicrobial effects of grape seed extract on peri implantitis microflora in craniofacial implants. Asian Pac. J. Trop. Biomed. 2(10), 822-825.

Singletary, K.W., Stansbury, M.J., Giusti, M., Breemen, R.B.V., Wallig, M. and Rimando A. 2003. Inhibition of rat mammary tumorigenesis by 
concord grape juice constituents. J. Agric. Food Chem. 51, 7280-7286.

Szeto, Y.P., Tomlinson, B. and Benzie, I.F.F. 2002. Total antioxidant and ascorbic acid content of fresh fruits and vegetables: Implications for dietary planning and food preservation. Br. J. Nutr. 87(1), 55-59.

Teissedre, P.L., Frankel, E.N., Waterhouse, A.L., Peleg, H. and German, J.B. 1996. Inhibition of in vitro human LDL oxidation by phenolic antioxidants from grapes and wines. J. Sci. Food Agric. 70, 55-61.

van der Watt, E. and Pretorius, J.C. 2001. Purification and identification of active antibacterial components in Carpobrotusedulis L. J. Ethnopharmacol. 76(1), 87-91.

Winkler, J.A. 1962. General viticulture, University of California Press, pp: 645. ISB 978-0-520-02591-2.

Yeung, C.K., Glahn, R.P. and Miller, D.D. 2006. Iron Bioavailability from Common Raisin-containing Foods Assessed with an In Vitro Digestion/Caco-2 Cell Culture Model: Effects of Raisins. J. Food Sci. 68(5), 1866-1870.

Yigit, D., Yigit, N., Mavi, A., Yildirim, A. and Guleryuz, M. 2009. Antioxidant and antimicrobial activities of methanol and water extracts of fruits, leaves and seeds of Vitis vinifera L. cv. Karaerik. Asian J. Chem. 21, 183-194. 